\title{
Potensi Antibakteri Sediaan Sabun Cair Ekstrak Kulit Nanas (Ananas comosus L. Merr.) Terhadap Bakteri Staphylococcus aureus ATCC 25923
}

\author{
Riesky Maulida ${ }^{1}$, Ismi Rahmawati ${ }^{1 *}$, Siti Aisyah ${ }^{1}$ \\ ${ }^{1}$ Fakultas Farmasi Universitas Setia Budi, Surakarta, Indonesia \\ *corresponding author \\ Email: ismirahmawati@setiabudi.ac.id
}

Diterima : 03 Mei 2021

Direvisi : 12 Oktober 2021

Publikasi : 20 Oktober 2021

doi:10.52216/jfsi.vol4no2p1-11

\begin{abstract}
Pineapple peels extract (Ananas comosus (L.) Merr.) has antibacterial activity against Staphylococcus aureus bacteria which causes skin infections. One of the infection prevention is by using antibacterial hand soap. This study aims to determine the physical quality, stability and antibacterial activity of the pineapple peels extract soap against S. aureus ATCC 25923. Pineapple peels extract obtained from maceration with $70 \%$ ethanol solvent was formulated into liquid hand washing soap. Soap formulations were made with the respective concentrations of 3\%, 6\%, and 9\%. Each formula was tested for physical quality with parameters: organoleptic, homogeneity, $\mathrm{pH}$, specific gravity, viscosity, and foaming capacity. Stability test using the freeze thaw method with organoleptic, $p H$, and viscosity. The formulation results were tested for antibacterial activity against S. aureus ATCC 25923 by the well diffusion method. Panelists testing was done with several respondents. Data analysis of physical quality, stability and activity was tested by SPSS statistics with a confidence level of 95\%. Pineapple peel extract contains flavonoids, alkaloids, tannins, saponins and phenols. All three soap formulas have physical quality in accordance with SNI 2588: 2017. The three formulas are stable until the fifth cycle (one cycle of 48 hours). The three liquid soap formulas had antibacterial activity against S. aureus ATCC 25923. The formula with a concentration of $9 \%$ was not significantly different from the positive control and had the highest inhibitory diameter of $21.78 \pm 0.84 \mathrm{~mm}$. The formula with a concentration of $9 \%$ were most preferred by the panelists.
\end{abstract}

Keywords: extract, Ananas comosus (L.) Merr., liquid soap, antibacterial, Staphylococcus aureus

\section{Intisari}

Ekstrak kulit buah nanas (Ananas comosus (L.) Merr.) mempunyai aktivitas antibakteri terhadap bakteri Staphylococcus aureus yang menyebabkan infeksi pada kulit. Salah satu pencegahan infeksi dengan menggunakan sabun cuci tangan antibakteri. Penelitian ini bertujuan untuk melihat mutu fisik, stabilitas dan aktivitas antibakteri dari sediaan sabun cair ekstrak kuit nanas terhadap S. aureus ATCC 25923. Ekstrak kulit buah nanas yang diperoleh dari maserasi dengan pelarut ethanol 70\%, diformulasikan menjadi sabun cair cuci tangan. Formulasi sabun cair dibuat dengan masing-masing konsentrasi 3\%, 6\%, dan 9\%. Sediaan sabun cair setiap formula di uji mutu fisik dengan parameter organoleptis, homogenitas, $p H$, berat jenis, viskositas, tinggi busa. Uji stabilitas dengan metode freeze thaw dengan parameter organoleptis, $\mathrm{pH}$, dan viskositas. Hasil formulasi diuji aktivitas antibakteri terhadap $S$. aureus ATCC 25923 dengan metode difusi sumuran. Sediaan dilakukan uji panelis dengan beberapa responden. Analisis data mutu fisik, stabilitas dan aktivitas diuji statistik SPSS dengan taraf kepercayaan 95\%. Ekstrak kulit nanas mengandung senyawa kimia flavonoid, alkaloid, tanin, saponin dan fenol. Hasil uji mutu fisik ketiga formula sabun cair ekstrak kulit nanas memiliki kualitas mutu fisik 
yang sesuai SNI 2588:2017. Uji stabilitas dengan metode freeze thaw ketiga sediaan stabil sampai siklus ke lima (satu siklus 48 jam). Ketiga formula sediaan sabun cair memiliki aktivitas antibakteri terhadap S. aureus ATCC 25923. Formula dengan konsentrasi 9\% tidak berbeda signifikan dengan kontrol positif dan memiliki diameter daya hambat yang paling tinggi sebesar 21,78 $\pm 0,84 m m$. Sediaan dengan konsentrasi $9 \%$ paling disukai para panelis.

Kata kunci: ekstrak, Ananas comosus (L.) Merr., sabun cair, antibakteri, Staphylococcus aureus

\section{Pendahuluan}

Kulit bagian tubuh yang cukup sensitif terhadap berbagai macam penyakit. Faktor-faktor yang mempengaruhi tingginya prevalensi penyakit kulit adalah iklim yang panas dan lembab kebersihan kulit perorangan yang kurang baik (Kemenkes RI, 2010). Tangan merupakan media yang sangat mudah untuk penyebaran penyakit dan infeksi pada manusia karena tangan kontak dengan lingkungan. Kebersihan tangan yang terjaga merupakan salah satu hal penting dalam langkah pencegahan penyakit yang disebabkan oleh infeksi mikroorganisme. Diare dan infeksi merupakan penyakit yang sering terjadi saat manusia tidak menjaga kebersihan tangan (Wulansari, N. T dan Parut A. A. 2019; Kurniawan et al., 2012).

Staphylococcus aureus bakteri flora normal yang oportunistis menginfeksi manusia yang dapat ditularkan secara langsung dari satu orang ke orang lain, misalnya melalui batuk, bersin, dan berciuman (Price dan Wilson, 2005). Bakteri $S$. aureus melekat di tangan dapat menyebabkan berbagai infeksi seperti pneumonia, meningitis, infeksi saluran kemih dan keracunan makanan dengan cara melepaskan enterotoksin ke dalam makanan. Perlu dilakukan tindak pencegahan agar mengurangi terjadinya infeksi bakteri (Thaker et al., 2009).

Penelitian ini Prasanti, A. N. (2010) kebiasaan cuci tangan pakai sabun mempunyai hubungan yang bermakna sebagai faktor yang berpengaruh terhadap reduksi jumlah $S$. aureus pada responden penelitian dibandingkan hanya mencuci dengan air saja. Berbagai jenis sabun yang beredar di pasaran dalam bentuk yang bervariasi, mulai dari sabun pencuci, sabun mandi, sabun tangan, sabun pembersih peralatan rumah tangga dalam bentuk krim, padat atau batangan, bubuk dan bentuk cair. Sabun cair dianggap penggunaannya lebih praktis dan bentuk menarik dibandingkan bentuk sabun lain. Sabun dapat digunakan untuk pengobatan penyakit, seperti mengobati penyakit kulit yang di sebabkan oleh bakteri dan jamur. Sabun dapat digunakan sebagai obat yakni dengan membersihkan tubuh dan lingkungan sehingga kemungkinan terserang penyakit akan berkurang (Ardina, 2017).

Sabun cair disukai karena pemakaiannya memberikan rasa nyaman pada pengguna dibandingkan dengan sediaan lainya. Kemudahan dicuci dengan air dan tidak memberikan kesan lengket, lebih mudah dalam penggunaannya, praktis bisa dibawa ke mana saja, higienis karena biasanya disimpan dalam wadah tertutup rapat (Muliyawan, Dewi dan Suriana, Neti (2013).

Kulit nanas merupakan limbah karena masyarakat biasanya hanya mengambil daging buahnya saja sedangkan kulit buahnya dibuang. Kulit buah nanas mengandung vitamin (A dan C), karotenoid, flavonoid, tanin, alkaloid, kalsium, fosfor, magnesium, besi, natrium dan enzim Bromelain. Bromelain adalah enzim proteolitik yang ditemukan pada bagian tangkai, batang, daun, buah, maupun kulit dalam jumlah yang berbeda. Limbah bagian kulit nanas yang biasanya ikut terbuang saat mengupas nanas paling banyak mengandung enzim Bromelain yang dapat menghambat pertumbuhan bakteri. Kulit nanas hanya dibuang begitu saja sebagai limbah, padahal kulit nanas mengandung vitamin $\mathrm{C}$, karotenoid, antosianin, flavonoid, enzim bromelain, air, serat kasar, gula reduksi, karbohidrat, protein, dan tanin. Enzim bromelain dapat digunakan sebagai efek antibakteri. Zat-zat dalam enzim bromelain dapat mengubah sifat fisik dan kimiawi selaput sel dan dapat menghalangi fungsi normalnya sehingga mampu menghambat dan membunuh bakteri tersebut. Senyawa lain yang terkandung dalam kulit nanas yang dapat digunakan sebagai antibakteri adalah flavonoid, saponin, dan tanin. 
Flavonoid merupakan senyawa fenol yang berfungsi sebagai antibakteri dan anti jamur. Saponin dan tanin merupakan suatu senyawa alami yang banyak terdapat pada tanaman didaerah tropis dan juga bersifat antibakteri (Damogalad et al., 2013).

Ekstrak kulit buah nanas berdasarkan penelitian Manaroinsong dan Jemmy (2015) mempunyai aktivitas antibakteri terhadap pertumbuhan bakteri $S$. aureus. Konsentrasi Hambat minimum (KHM) ekstrak kulit nanas terhadap S. aureus sebesar 1,56\% (Wirhaningtyas et al., 2016). Ekstrak kulit nanas memiliki diameter daya hambat yang cukup kuat 10,33 mm pada konsentrasi 0,5398 g/mL (Punbusayakul et al., 2018).

Salah satu cara yang dapat dilakukan sebagai pencegahan dengan menjaga kebersihan tangan sebelum makan dan minum dengan menggunakan sabun antiseptik tangan. Berbagai produk yang mengandung zat antibakteri, khususnya sabun cair saat ini banyak dikembangkan (Erukainure et al., 2011). Salah satu keanekaragaman hayati yang memiliki potensi untuk dikembangkan sebagai antiseptik adalah limbah kulit buah nanas yang mengandung senyawa kimia yang bersifat sebagai antibakteri. Berdasarkan latar belakang tersebut peneliti tertarik untuk memformulasikan ekstrak kulit nanas dengan berbagai konsentrasi yakni $3 \%, 6 \%$, dan $9 \%$ dalam formulasi sediaan sabun cair yang efektif terhadap pertumbuhan bakteri $S$. aureus yang memiliki kualitas mutu fisik dan stabilitas sediaan yang baik.

\section{Metode Penelitian}

\subsection{Alat dan bahan}

Alat yang digunakan meliputi alat-alat gelas, blender, timbangan digital, $p \mathrm{H}$ meter, Moisture Balance, seperangkat alat destilasi, oven, gunting, kertas saring, kain flanel, botol coklat, corong, desikator, piknometer, pipet tetes, Rotary Vacum Evaporator, inkubator, jarum ose, autoklaf, ayakan mesh nomor 40, jangka sorong, waterbath, wadah, pisau, viskometer brookfield, tabung reaksi, rak tabung, enkas, dan bunsen, brooprop, beakerglass, erlenmeyer, oven, kertas saring, corong, spatel Drigalski, pinset, botol plastik, batang pengaduk, cawan porselin, kertas timbang, sendok tanduk, penggaris.
Bahan yang digunakan meliputi kulit buah nanas (Ananas comosus (L) Merr), etanol 70\%, $\mathrm{H}_{2} \mathrm{SO}_{4}$ pekat, $\mathrm{CH}_{3} \mathrm{OOH}, \mathrm{HCl} 2 \mathrm{~N}$, Baochardat LP, Dragendroff $L P, \mathrm{FeCl} 0,1 \mathrm{~N}$, asam stearat, $\mathrm{NaCl}$, $\mathrm{KOH}$, gliserin, EDTA, akuades, Nutrient Agar (NA), pereaksi Mayer, metanol, serbuk $\mathrm{Mg}$, kloroform, $\mathrm{H}_{2} \mathrm{SO}_{4}$ pekat, $\mathrm{HCl} 10 \%$, BHI (Brain Heart Infusion) Agar, kalium telurit 1\%, Gram A, Gram B, Gram C, Gram D, minyak emersi, Mannitol Salt Agar (MSA), standard 0,5 McFarland, plasma darah kelinci, $\mathrm{H}_{2} \mathrm{O}_{2}$.

\subsection{Rancangan Penelitian}

Determinasi dan pembuatan simplisia kulit nanas. Determinasi ini dilakukan di Badan Penelitian dan Pengembangan Tanaman Obat dan Obat Tradisional di Tawangmangu, Karanganyar, Jawa Tengah. kulit nanas yang berwarna oranye, tidak terlalu tua juga tidak terlalu muda, masih segar dari kota Tenggarong, Kalimantan Timur pada bulan September 2019. Pembuatan simplisia dengan cara kulit buah nanas dicuci bersih dengan air mengalir kemudian dipisahkan dari daging buah dan durinya dipotong-potong kecil. Potongan kulit nanas kemudian dikeringkan dengan cara diangin-anginkan pada suhu ruang dan terhindar dari sinar matahari langsung. Penjemuran dilakukan beberapa hari, sampai potongan kulit benar-benar kering hingga dihasilkan simplisia kulit buah nanas (Salasa, 2017).

Pembuatan serbuk dan ekstrak kulit nanas. Serbuk kulit nanas yang sudah kering diserbuk dengan alat penyerbuk kemudian diayak dengan ayakan nomor 40 sehingga diperoleh serbuk kulit nanas yang mempunyai derajat kehalusan relatif homogen. Serbuk kering 900 gram di maserasi dengan pelarut etanol $70 \%$ sebanyak $9000 \mathrm{~mL}$. Rendam selama 6 jam pertama sambil sekali-kali diaduk, kemudian diamkan selama 18 jam. Pisahkan maserat dengan cara pengendapan. Kemudian disaring dengan kain flanel dan dilanjutkan dengan kertas saring. Proses penyarian sekurang-kurangnya dua kali dengan jenis dan jumlah pelarut yang sama. Kumpulkan semua maserat, kemudian uapkan dengan penguap vakum atau penguap tekanan rendah hingga diperoleh ekstrak kental. Hitung rendemen yang 
diperoleh yaitu persentase bobot (b/b) antara rendemen dengan bobot serbuk simplisia yang digunakan dengan penimbangan.

Identifikasi senyawa kimia ekstrak kulit buah nanas. Uji senyawa alkaloid dengan uji Baochardat dan Dragendroff (Depkes RI, 1995). Uji Flavonoid dengan cara ekstrak dilarutkan menggunakan akuades hangat dan disaring kemudian ditambahkan $250 \mathrm{mg}$ serbuk seng, dimasukkan dalam amil alkohol yaitu campuran $\mathrm{HCl} 2 \mathrm{~N}$ dan ethanol $96 \%$ dengan volume sama. Pengamatan dilakukan dengan melihat perubahan warna yang terjadi pada larutan. Terbentuknya warna merah, kuning, atau jingga pada lapisan amil alkohol positif menunjukkan adanya kandungan senyawa flavonoid dalam ekstrak etanol kulit nanas (Depkes RI, 1995). Uji Saponin dengan cara ekstrak kulit buah nanas ditambah dengan air panas $10 \mathrm{~mL}$, didinginkan lalu dikocok selama 10 detik. Kemudian didiamkan selama 10 menit. Saponin positif bila muncul buih yang tinggi $1-10 \mathrm{~cm}$. Terdapat buih yang stabil walaupun ditambahkan HCL $2 \mathrm{~N}$ (buih tidak hilang) (Depkes, 1995). Pengujian terhadap tanin dengan cara ekstrak kulit buah nanas yang telah dilarutkan dengan akuades hangat dan disaring kemudian ditetesi dengan 2 tetes larutan $\mathrm{FeCl} 0,1$ $\mathrm{N}$ menghasilkan larutan berwarna coklat kehitaman, yang berarti bahwa ekstrak kulit nanas positif mengandung tanin dimana senyawa tanin yang berada di dalam ekstrak akan bereaksi dengan $\mathrm{FeCl} 3$ dan terbentuklah ikatan ionik yang menyebabkan warna coklat kehitaman (Depkes, 1995). Uji Fenol dengan cara ekstrak kulit buah nanas dimasukkan ke dalam tabung reaksi, selanjutnya ditambahkan pereaksi $\mathrm{FeCl} 3$ dalam larutan etanol, hasil positif ditunjukkan dengan adanya warna hijau, merah ungu, biru dan hitam (Harborne, 1998).

\section{Pembuatan sediaan sabun cair ekstrak nanas.}

Semua bahan yang akan digunakan ditimbang terlebih dahulu sesuai dengan takaran yang dianjurkan (tabel 1). Masukkan asam stearat ke dalam gelas beker, kemudian ditambahkan $\mathrm{NaCl}$ yang telah dilarutkan dengan air dan $\mathrm{KOH}$, lalu dilarutkan dengan akuades di atas penangas sambil diaduk hingga homogen. Tambahkan EDTA dan gliserin ke dalam gelas beker dan diaduk hingga homogen. Masukkan ekstrak kulit nanas dengan masing-masing konsentrasi 3\%, 6\%, dan $9 \%$, diaduk hingga homogen. Sabun cair ditambahkan dengan akuades hingga volumenya $100 \mathrm{~mL}$, dimasukkan ke dalam wadah bersih yang telah disiapkan.

Tabel 1. Formula sabun cair ekstrak kulit nanas

\begin{tabular}{|c|c|c|c|c|}
\hline \multirow[b]{2}{*}{ Bahan } & \multicolumn{4}{|c|}{ Formula Persentase (b/v) \% } \\
\hline & $\begin{array}{c}\text { Formula } \\
1\end{array}$ & $\begin{array}{c}\text { Formula } \\
2\end{array}$ & $\begin{array}{c}\text { Formula } \\
3\end{array}$ & $\begin{array}{l}\text { Kontrol } \\
\text { Negatif }\end{array}$ \\
\hline $\begin{array}{l}\text { Ekstrak kulit } \\
\text { nanas }\end{array}$ & 3 & 6 & 9 & - \\
\hline Asam stearat & 3 & 3 & 3 & 3 \\
\hline $\mathrm{NaCl}$ & 1 & 1 & 1 & 1 \\
\hline $\mathrm{KOH}$ & 1,5 & 1,5 & 1,5 & 1,5 \\
\hline Gliserin & 10 & 10 & 10 & 10 \\
\hline EDTA & 0,5 & 0,5 & 0,5 & 0,5 \\
\hline Akuades & ad 100 & ad 100 & ad 100 & ad 100 \\
\hline
\end{tabular}

Pengujian Mutu Fisik dan Stabilitas Sediaan. Pengujian mutu fisik dilihat setelah sediaan sabun cair cuci tangan ekstrak kulit nanas jadi sediaan. Pengujian stabilitas sabun cair dengan menggunakan metode freeze thaw untuk mengetahui stabilitas sediaan sabun cair ekstrak kulit nanas yang dibuat berdasarkan penyimpanan pada suhu yang berbeda. Pengujian stabilitas ini dilakukan dengan menggunakan penyimpanan sediaan sabun cair pada suhu $4^{\circ} \mathrm{C}$ selama 48 jam dan kemudian dipindahkan pada suhu $40^{\circ} \mathrm{C}$ selama 48 jam (1 siklus) dan dilanjutkan sampai lima siklus. Parameter yang digunakan dalam penentuan mutu fisik dan stabilitas sabun cair yaitu organoleptis, $\mathrm{pH}$ dan uji viskositas (Warnida et al., 2014).

Pemeriksaan organoleptik dan homogenitas Sediaan yang sudah diformulasikan kemudian dilakukan pengamatan penampilan menggunakan pancaindra meliputi bau, warna dan bentuk sediaan. Pemeriksaan homogenitas dilakukan dengan mengoleskan sampel di atas objek glass kemudian direkatkan dengan objek glass yang lain dan diamati homogenitasnya.

Pemeriksaan bobot jenis. Pemeriksaan bobot jenis dilakukan dengan alat piknometer yang sudah dikeringkan dan ditimbang. Sampel didinginkan sampai suhu $25^{\circ} \mathrm{C}$ dan dimasukkan ke dalam piknometer, tutup rapat lalu timbang. 
Lakukan pemeriksaan pembanding menggunakan akuades.

Pemeriksaan pH. Kalibrasi $\mathrm{pH}$ meter dengan larutan standar buffer, bilas dengan air suling bebas $\mathrm{CO}_{2}$ dan keringkan elektroda dengan tisu, celupkan elektroda ke dalam sampel sambil diaduk, catat hasil pembacaan $\mathrm{pH}$ pada tampilan pH meter (Kemenkes RI, 2017).

Pemeriksaan viskositas. Masukkan sampel ke dalam wadah, dimasukkan juga spindel ke dalamnya sampai tanda batas, lepaskan klep pengaman dan rotor dihidupkan. Biarkan hingga skala menunjukkan angka yang stabil.

Pemeriksaan stabilitas busa. Masukkan $1 \mathrm{~mL}$ sampel ke dalam tabung reaksi. Tambahkan air sebanyak $9 \mathrm{~mL}$, aduk hingga larut dan kocok selama 20 detik. Ukur tinggi busa yang terbentuk. Ukur kembali tinggi busanya setelah didiamkan selama 5 menit (Agustina et al., 2017).

Penentuan aktivitas antibakteri. Bakteri $S$. aureus ATCC 25923 diidentifikasi kesesuaian dengan pustaka, selanjutnya dibuat suspensi bakteri dengan kekeruhan sama dengan McFarland 0,5. Medium NA (Nutrient Agar) di kultur dengan suspensi bakteri dengan cara perataan. Dibuat 5 sumuran dengan menggunakan boorprop pada media NA . Sumuran nomor 1 diisi kontrol negatif sabun cair cuci tangan tanpa ekstrak kulit buah nanas, sumuran nomor 2 diisi sabun cair cuci ekstrak kulit buah nanas dengan konsentrasi 3\%, sumuran nomor 3 diisi sabun cair cuci ekstrak kulit buah nanas dengan konsentrasi $6 \%$, sumuran nomor 4 diisi sabun cair cuci ekstrak kulit buah nanas dengan konsentrasi $9 \%$, sumuran nomor 5 diisi kontrol positif sabun cair cuci merek "SS", masing-masing sumuran di isi sebanyak 50 $\mu \mathrm{L}$ dan di buat 3 replikasi. Kemudian diinkubasi pada suhu $37^{\circ} \mathrm{C}$ selama 24 jam. Pengamatan dilakukan pada zona jernih di sekitar sumuran yang terbentuk karena daya hambat sediaan terhadap pertumbuhan bakteri.

Uji panelis. Uji panelis dengan parameter warna, aroma, kesan kesat, kelembapan, dan kesegaran kulit setelah digunakan. Uji panelis dilakukan secara eksperimental oleh 15 sukarelawan. Uji panelis pada produk sabun cuci tangan cair dilakukan untuk mengetahui tingkat kesukaan panelis terhadap penampilan (warna), bau (aroma), kekentalan, banyak busa, penilaian umum, meliputi: kelembutan maupun kesan kesat pada kulit. Setiap panelis diminta untuk menuangkan sabun cair ke telapak tangan, masing-masing formula dengan berbagai konsentrasi. Panelis kemudian diminta untuk menilai dan mengisi kuesioner dengan (1) bila tidak suka (2) bila kurang suka, (3) bila suka, dan (4) bila sangat suka. Kemudian dihitung persentase kesukaan terhadap masing-masing sediaan dan dianalisis secara statistik untuk penarikan kesimpulan (Amalia et al., 2017).

\subsection{Analisis Data}

Sabun cair dari masing-masing formula diuji sifat fisiknya yang meliputi organoleptis, $p \mathrm{H}$, homogenitas, viskositas, bobot jenis, uji tinggi busa dan uji aktivitas antibakteri dianalisis secara statistik SPSS metode analysis of varian (ANOVA) One Way dengan taraf kepercayaan $95 \%$.

\section{Hasil dan Pembahasan}

3.1. Determinasi dan Pembuatan Serbuk Tanaman Nanas (Ananas comosus (L.) Merr.)

Determinasi tanaman dalam penelitian ini dilakukan di Balai Besar Penelitian dan Pengembangan Tanaman Obat dan Obat Tradisional (B2P2TOOT), Tawangmangu, Kabupaten Karanganyar, Jawa Tengah. Berdasarkan Surat Keterangan Determinasi Nomor: 023/H6 - 04113.08.2020 dapat dipastikan bahwa tanaman yang digunakan dalam penelitian ini adalah tanaman nanas (Ananas comosus (L.) Merr). Kulit disortasi dan dicuci dengan air bersih untuk menghilangkan kotoran yang menempel, kulit dikeringkan pada suhu ruang. Persentase rendemen serbuk kulit nanas diperoleh sebesar 75 $\%$. Berdasarkan pemeriksaan organoleptis yang telah dilakukan didapat hasil bahwa serbuk kulit nanas memiliki bentuk yang serbuk halus, berwarna coklat muda, berbau khas nanas, dan berasa sepat.

\subsection{Hasil Pembuatan Ekstrak Kulit Nanas}


Hasil persentase rendemen ekstrak etanol 70 $\%$ kulit nanas yang diperoleh sebanyak 41,67 \%, semakin tinggi nilai rendemen menandakan jumlah metabolit yang terekstraksi semakin banyak. Persentase rendemen sangat dipengaruhi lingkungan tempat tumbuh simplisia. Kondisi dataran tempat tumbuh dari permukaan laut, keadaan tanah, cuaca, musim, keadaan dan lama sinar matahari, suhu, dan curah hujan (Mediani, A. et al., 2012)

\subsection{Hasil identifikasi kandungan kimia ekstrak kulit nanas}

Berdasarkan pemeriksaan organoleptis yang telah dilakukan didapat hasil bahwa ekstrak kulit nanas memiliki bentuk ekstrak kental, berwarna coklat kehitaman pekat, berbau khas nanas, dan berasa sepat. Pelarut pengekstraksi menentukan zat warna yang terekstraksi. Ini ditunjukkan dengan pelarut pengekstraksi etanol memberikan warna coklat kehitaman. Ini menunjukkan, kepolaran pelarut pengekstraksi menentukan jenis pigmen zat warna yang terekstrak (Kristianti, 2008). Pengaruh panas tidak mempengaruhi zat warna yang diekstrak dan ini menunjukkan panas tidak merusak kandungan zat warna yang terdapat pada kulit nanas (Hagerman, A. E, 2002). Hasil uji identifikasi kandungan kimia pada kulit nanas terdapat senyawa flavonoid, alkaloid, tanin, saponin dan fenol (tabel 2). Hasil identifikasi sesuai dengan penelitian Dabesor A. P., 2017 yang menyatakan terdapat oxalate, alkaloids, phytate, tannins and glycoside.

Tabel 2. Hasil identifikasi kandungan kimia ekstrak kulit nanas

\begin{tabular}{|c|c|c|}
\hline $\begin{array}{c}\text { Nama } \\
\text { senvawa }\end{array}$ & Hasil uji & Kesimpulan \\
\hline Flavonoid & $\begin{array}{c}\text { Terbentuk jingga hingga warna } \\
\text { merah (flavon) }\end{array}$ & + \\
\hline Alkaloid & $\begin{array}{l}\text { Terbentuk endapan coklat } \\
\text { kehitaman (Buchardat LP) dan } \\
\text { terbentuk endapan coklat } \\
\text { kemerahan (Dragendroff LP) }\end{array}$ & + \\
\hline Tanin & $\begin{array}{c}\text { Terbentuk warna coklat } \\
\text { kehitaman }\end{array}$ & + \\
\hline Saponin & $\begin{array}{c}\text { Terbentuk busa yang tidak } \\
\text { hilang walaupun ditambahkan } \\
\text { HCL } 2 \mathrm{~N}\end{array}$ & + \\
\hline Fenol & $\begin{array}{l}\text { Terbentuk warna } \\
\text { hijau kehitaman }\end{array}$ & + \\
\hline
\end{tabular}

3.4. Hasil pengujian mutu fisik sediaan sabun cair
Hasil pengujian organoleptik yang diperoleh terhadap pemeriksaan hasil sediaan sabun cair cuci tangan ekstrak kulit nanas dapat dilihat pada tabel 3. Homogenitas sabun dapat dilihat dengan adanya keseragaman warna dalam basis secara visual terlihat merata. Hasil pengamatan kelima formula menunjukkan sediaan homogen merata di seluruh bagian. Semua formula tidak terdapat partikel kasar dalam sediaan.

Hasil pemeriksaan $\mathrm{pH}$ sabun cair cuci tangan ekstrak kulit nanas dilakukan dengan menggunakan $\mathrm{pH}$ stik. Hasil $\mathrm{pH}$ sediaan sabun cair cuci tangan ekstrak kulit nanas didapatkan pada kontrol negatif dan positif yaitu 7 , formula 1 , 2 , dan 3 yaitu 8 . Hasil $\mathrm{pH}$ adanya perbedaan antara basis sediaan sabun cair dengan formula sabun cair yang mengandung ekstrak karena dipengaruhi oleh ekstrak pada semua formula mengalami kenaikan dibandingkan dengan basisnya. Hasil pH semua sediaan sabun cair cuci tangan ekstrak kulit nanas memenuhi persyaratan Standar Nasional Indonesia (SNI) 2017 yaitu rentang 6-11 (BSN, 2017). Produk sabun cair memiliki pH yang cenderung basa, hal ini dikarenakan bahan dasar penyusun sabun terdapat $\mathrm{KOH}$, bersifat basa kuat. Sabun adalah garam alkali dari asam lemak suku tinggi sehingga akan dihidrolisis parsial oleh air. Karena itu larutan sabun dalam air bersifat basa. Nilai $\mathrm{pH}$ sabun yang terlalu rendah dapat menyebabkan peningkatan daya absorbsi sabun pada kulit sehingga dapat menyebabkan iritasi pada kulit, sedangkan nilai $\mathrm{pH}$ yang terlalu tinggi juga dapat menyebabkan iritasi pada kulit (Hernani, 2010).

Viskositas merupakan salah satu parameter mutu fisik yang dapat mempengaruhi kemudahan sediaan untuk mengalir. Hasil analisis uji viskositas sediaan sabun cair ekstrak kulit nanas dengan SPSS one way ANOVA dilanjutkan Post Hoc dengan taraf kepercayaan 95\%, dapat diketahui formula 1 sebanding dengan kontrol negatif. Formula 2 dan 3 tidak berbeda secara bermakna. Semua formula belum sebanding secara bermakna dengan kontrol positif. Penambahan konsentrasi ekstrak kulit nanas mempengaruhi viskositas sediaan sabun cair. Semakin tinggi konsentrasi ekstrak kulit nanas yang digunakan maka viskositasnya semakin turun. Viskositas yang turun menyebabkan 
sediaan sabun cair menjadi lebih sedikit cair dan lebih mudah dituangkan.

Busa merupakan salah satu parameter untuk menentukan mutu produk sabun. Busa stabil dalam waktu lama lebih diinginkan karena busa dapat membantu membersihkan tubuh. Karakteristik busa sabun dipengaruhi oleh beberapa faktor yaitu adanya bahan surfaktan, penstabil busa dan bahan-bahan penyusun sabun cair lainnya (Pradipto, 2009). Hasil penelitian yang diperoleh semakin tinggi konsentrasi maka semakin tinggi busa. Ekstrak kulit nanas mengandung senyawa saponin yang menghasilkan busa. Hasil uji tinggi busa pada ketiga sediaan sabun cair ekstrak kulit nanas memenuhi standar SNI. Standar tinggi busa dari sabun cair yaitu 1,3$22 \mathrm{~cm}$ (BSN, 2017). Hasil uji tinggi busa ketiga sediaan sabun cair ekstrak kulit nanas memenuhi standar SNI. Data dianalisis menggunakan SPPS one way ANOVA dilanjutkan Post Hoc dengan taraf kepercayaan 95\% menunjukkan bahwa terdapat perbedaan yang bermakna antara kontrol negatif dengan formula 2 dan kontrol negatif dengan formula 3, sehingga dapat dikatakan bahwa penambahan konsentrasi ekstrak kulit nanas mempengaruhi tinggi busa sediaan sabun cair. Busa adalah gas yang terjebak oleh lapisan tipis cairan yang mengandung sejumlah molekul surfaktan yang teradsorpsi pada lapisan tipis tersebut, dalam gelembung gugus hidrofobik surfaktan akan mengarah ke gas, sedang bagian hidrofiliknya akan mengarah kelarutan. Gelembung akan dilapisi oleh lapisan tipis cairan yang mengandung sejumlah molekul surfaktan dengan orientasi face to face saat gelembung keluar dari badan cairan (Tadros, 2005).

Hasil uji berat jenis ketiga sediaan sabun cair ekstrak kulit nanas memenuhi standar SNI, data dapat dilihat pada tabel 3. Data SNI, standar bobot jenis pada sabun cair yaitu 1,01-1,1 g/ml. Data dianalisis menggunakan SPPS one way ANOVA dilanjutkan Post Hoc dengan taraf kepercayaan 95\% menunjukkan masing-masing formula terdapat perbedaan yang bermakna. Hasil uji bobot jenis sediaan sabun cair cuci tangan ekstrak kulit nanas didapatkan semakin tinggi konsentrasi ekstrak maka semakin rendah bobot sediaan sabun cair. Hasil tersebut dipengaruhi oleh ekstrak kulit nanas, dimana semakin tinggi konsentrasi maka konsistensi sediaan sabun cair semakin cair.

3.5. Hasil uji stabilitas sediaan sabun cair metode freeze thaw.

Pengujian stabilitas sabun cair dengan menggunakan metode freeze thaw adalah untuk mengetahui stabilitas sediaan sabun cair cuci tangan ekstrak kulit nanas yang dibuat berdasarkan penyimpanan pada suhu yang berbeda. Pengujian stabilitas ini dilakukan dengan menggunakan penyimpanan sediaan sabun cair pada suhu $4^{\circ} \mathrm{C}$ selama 48 jam dan kemudian dipindahkan pada suhu $40^{\circ} \mathrm{C}$ selama 48 jam (1 siklus) dan dilanjutkan sampai lima siklus. Parameter yang digunakan dalam penentuan stabilitas sabun cair yaitu organoleptis, $\mathrm{pH}$ dan uji viskositas (Warnida et al., 2014).

Hasil pengamatan secara visual uji stabilitas organoleptik sabun cair cuci tangan ekstrak kulit nanas pada tabel 4 menunjukkan bahwa penyimpanan pada lima siklus di suhu yang berbeda tidak mengalami perubahan fase/pemisahan yang berarti dapat disimpulkan bahwa sediaan sabun cair cuci tangan ekstrak kulit nanas stabil. Setelah dilakukan uji $\mathrm{pH}$ maka di dapatkan data hasil pengamatan terhadap $\mathrm{pH}$ kelima formula sebelum dan setelah uji kestabilan dengan freeze thaw terlihat stabil, karena tidak terjadi perubahan sebelum dan sesudah dilakukan

Tabel 3. Hasil uji mutu fisik sediaan sabun cair ekstrak kulit nanas

\begin{tabular}{|c|c|c|c|c|c|c|c|c|}
\hline \multirow{2}{*}{ Formula } & \multicolumn{3}{|c|}{ Organoleptik } & \multirow[t]{2}{*}{ Homogenitas } & \multirow[t]{2}{*}{ pH } & \multirow[t]{2}{*}{ Viskositas } & \multirow{2}{*}{$\begin{array}{l}\text { tinggi busa } \\
\text { (cm) }\end{array}$} & \multirow{2}{*}{$\begin{array}{c}\text { bobot jenis } \\
(\mathrm{g} / \mathrm{ml})\end{array}$} \\
\hline & Warna & Bau & Bentuk & & & & & \\
\hline $\begin{array}{c}\text { Kontrol } \\
(-)\end{array}$ & Putih & $\begin{array}{c}\text { tidak } \\
\text { berbau }\end{array}$ & $\begin{array}{l}\text { Sangat } \\
\text { kental }\end{array}$ & Homogen & 7 & $7,33 \pm 0,29^{\mathrm{a}}$ & $3,85 \pm 0,42^{\mathrm{a}}$ & $1,014 \pm 0,001^{\mathrm{a}}$ \\
\hline $\begin{array}{l}\text { Formula } 1 \\
\quad(3 \%)\end{array}$ & $\begin{array}{c}\text { Coklat } \\
\text { keemasan }\end{array}$ & khas nanas & $\begin{array}{l}\text { Sangat } \\
\text { kental }\end{array}$ & Homogen & 8 & $6,67 \pm 0,58^{a}$ & $1,90 \pm 0,20^{\mathrm{ab}}$ & $1,014 \pm 0,001^{\mathrm{a}}$ \\
\hline $\begin{array}{c}\text { Formula } 2 \\
\quad(6 \%)\end{array}$ & $\begin{array}{c}\text { Coklat } \\
\text { keemasan }\end{array}$ & khas nanas & Kental & Homogen & 8 & $4,77 \pm 0,25^{\mathrm{b}}$ & $2,23 \pm 0,15^{\mathrm{b}}$ & $1,020 \pm 0,000^{\mathrm{b}}$ \\
\hline $\begin{array}{c}\text { Formula } 3 \\
\qquad(9 \%)\end{array}$ & $\begin{array}{l}\text { Coklat } \\
\text { muda }\end{array}$ & khas nanas & $\begin{array}{c}\text { Sedikit } \\
\text { kental }\end{array}$ & Homogen & 8 & $4,63 \pm 0,31^{\mathrm{b}}$ & $2,73 \pm 0,25^{\mathrm{c}}$ & $1,050 \pm 0,001^{\mathrm{c}}$ \\
\hline $\begin{array}{c}\text { Kontrol } \\
(+)\end{array}$ & $\begin{array}{l}\text { Putih } \\
\text { silver }\end{array}$ & khas wangi & $\begin{array}{l}\text { Sangat } \\
\text { kental }\end{array}$ & Homogen & 7 & $9,92 \pm 0,38^{c}$ & $3,47 \pm 0,25^{\mathrm{c}}$ & $1,051 \pm 0,000^{\mathrm{c}}$ \\
\hline
\end{tabular}


uji stabilitas freeze thaw, uji pada $\mathrm{pH}$ ditemukan hasil yang sama antara keseluruhan formula yaitu memiliki pH 7 pada basis dan kontrol positif dan pH 8 pada formula I, II, dan III. Hal ini menunjukkan bahwa formulasi sabun cair antibakteri memiliki stabilitas fisik yang baik jika dilihat dari kestabilan $\mathrm{pH}$.

Uji viskositas dilakukan untuk melihat perubahan viskositas sediaan sabun cuci tangan selama penyimpanan. Hasil uji viskositas mengalami penurunan angka viskositas sebelum dan sesudah siklus freeze thaw. Penurunan viskositas ini dapat disebabkan karena pengaruh gliserin yang bersifat higroskopis yaitu mampu menyerap uap air dari luar sehingga kandungan air dalam sediaan semakin banyak. Kandungan air yang banyak menyebabkan sediaan sabun cuci tangan menjadi semakin encer dan viskositasnya semakin kecil (Rowe et al., 2009). Uji stabilitas viskositas dianalisis dengan SPPS Anova two way dilanjutkan dengan Tukey dengan taraf kepercayaan 95\% menunjukkan tidak ada perbedaan yang signifikan antara sebelum dan sesudah uji stabilitas. Hal ini menunjukkan bahwa formulasi sabun cair antibakteri memiliki stabilitas fisik yang baik jika dilihat dari kestabilan viskositas.

\subsection{Hasil pengujian aktivitas antibakteri sediaan} sabun cair cuci tangan ekstrak kulit nanas

Pengujian ini menggunakan metode difusi secara hot plate/sumuran yaitu dengan cara memasukkan sediaan sabun cuci tangan pada lubang di agar plate yang telah diinokulasikan mikroba. Sabun masing-masing formula dimasukkan kurang lebih 50 mikroliter ke dalam sumuran dalam media Nutrient Agar (NA). Sediaan uji diinkubasi dan diukur zona hambat bening yang merupakan penghambatan dari pertumbuhan mikroba oleh sediaan uji atau ekstrak (Hermawan et al 2007). Hasil pengujian aktivitas antibakteri secara difusi dapat dilihat pada tabel 21 . yang digunakan, dan bisa diterapkan pada bagian yang memiliki format serupa.

Hasil pengujian aktivitas antibakteri sediaan sabun cair cuci tangan ekstrak kulit nanas secara difusi dengan konsentrasi yaitu 3\%, 6\%, dan 9\% pada setiap formula, pembanding kontrol positif yang digunakan adalah sabun cuci tangan yang ada di pasaran karena sudah terbukti klinis yang dapat menghambat pertumbuhan bakteri Gram positif terutama terhadap $S$. aureus, sedangkan kontrol negatif adalah sabun tanpa ekstrak. Hasil daya hambat dari semua formula memiliki daya hambat yang berbeda.

Tabel 4. Hasil uji stabilitas sediaan sabun cair ekstrak kulit nanas dengan metode freeze thaw

\begin{tabular}{|c|c|c|c|c|}
\hline Formula & $\begin{array}{l}\text { Waktu } \\
\text { freeze } \\
\text { thaw }\end{array}$ & Organoleptis & pH & $\begin{array}{c}\text { Uji } \\
\text { viskositas }\end{array}$ \\
\hline \multirow{2}{*}{$\begin{array}{c}\text { Kontrol } \\
(-)\end{array}$} & Sebelum & $\begin{array}{l}\text { Tidak ada } \\
\text { perubahan, } \\
\text { Homogen, }\end{array}$ & 7 & $7,33 \pm 0,29$ \\
\hline & Sesudah & $\begin{array}{c}\text { putih, tidak } \\
\text { berbau, sangat } \\
\text { kental }\end{array}$ & 7 & $6,93 \pm 0,12$ \\
\hline \multirow{3}{*}{$\begin{array}{l}\text { Formula } \\
1(3 \%)\end{array}$} & Sebelum & $\begin{array}{l}\text { Tidak ada } \\
\text { perubahan, } \\
\text { Homogen }\end{array}$ & 8 & $6,67 \pm 0,58$ \\
\hline & & coklat & & \\
\hline & Sesudah & $\begin{array}{l}\text { keemasan, } \\
\text { khas nanas, } \\
\text { sangat kental }\end{array}$ & 8 & $6,77 \pm 0,25$ \\
\hline \multirow{3}{*}{$\begin{array}{c}\text { Formula } \\
2(6 \%)\end{array}$} & Sebelum & $\begin{array}{l}\text { Tidak ada } \\
\text { perubahan, }\end{array}$ & 8 & $4,77 \pm 0,40$ \\
\hline & & $\begin{array}{l}\text { Homogen, } \\
\text { coklat }\end{array}$ & & \\
\hline & Sesudah & $\begin{array}{c}\text { keemasan, } \\
\text { khas nanas, } \\
\text { kental }\end{array}$ & 8 & $5,37 \pm 0,32$ \\
\hline \multirow{2}{*}{$\begin{array}{c}\text { Formula } \\
3(9 \%)\end{array}$} & Sebelum & $\begin{array}{l}\text { Tidak ada } \\
\text { perubahan, }\end{array}$ & 8 & $4,63 \pm 0,31$ \\
\hline & Sesudah & $\begin{array}{l}\text { Homogen, } \\
\text { coklat muda, } \\
\text { khas nanas, } \\
\text { sedikit kental }\end{array}$ & 8 & $4,23 \pm 0,25$ \\
\hline
\end{tabular}

Tabel 5. Hasil uji aktivitas antibakteri sediaan sabun cair ekstrak kulit nanas terhadap $S$. aureus ATCC 25923

\begin{tabular}{cc|c|cc}
\hline $\begin{array}{c}\text { Formul } \\
\text { a }\end{array}$ & $\begin{array}{c}\text { Replikas } \\
\text { i 1 }\end{array}$ & $\begin{array}{c}\text { Replikas } \\
\text { i 2 }\end{array}$ & $\begin{array}{c}\text { Replikas } \\
\text { i 3 }\end{array}$ & $\begin{array}{c}\text { Rata- } \\
\text { rata } \pm S D\end{array}$ \\
\hline $\begin{array}{c}\text { Kontrol } \\
(-)\end{array}$ & 9,33 & 10 & 8,67 & $\begin{array}{c}9,33 \pm 0,67^{\mathrm{a}} \\
15,33 \pm 1,34 \\
3 \%\end{array}$ \\
14 & 16,67 & 15,33 & $\begin{array}{c}\mathrm{b} \\
\mathrm{b}\end{array}$ \\
$6 \%$ & 18,67 & 19 & 19,33 & $\begin{array}{c}19,00 \pm 0,33 \\
\mathrm{c}\end{array}$ \\
$9 \%$ & 22,67 & 21 & 21,67 & $\begin{array}{c}21,78 \pm 0,84 \\
\mathrm{~d}\end{array}$ \\
$\begin{array}{c}\text { Kontrol } \\
(+)\end{array}$ & 22 & 23,67 & 23,67 & $\begin{array}{c}23,11 \pm 0,96 \\
\mathrm{~d}\end{array}$ \\
\hline
\end{tabular}


Hasil penelitian (Damogalad et al., 2013) ekstrak kulit nanas terkandung berbagai senyawa, di antaranya flavonoid, tanin, alkaloid dan saponin. Senyawa flavonoid berfungsi sebagai antibakteri dengan cara membentuk senyawa kompleks dengan protein ekstraseluler, protein terlarut, serta mengganggu integritas membran sel bakteri. Mekanisme kerja antibakteri tanin mempunyai daya antibakteri dengan cara memprepitasi protein. Mekanisme kerja alkaloid sebagai antibakteri yaitu dengan cara mengganggu komponen penyusun peptidoglikan pada sel bakteri, sehingga lapisan dinding sel tidak terbentuk secara utuh dan menyebabkan kematian sel tersebut (Karou, 2005). Mekanisme kerja saponin sebagai antibakteri yaitu dapat menyebabkan kebocoran protein dan enzim dari dalam sel (Madduluri et al., 2013).

Hasil uji daya hambat bakteri $S$. aureus dilanjutkan dengan statistik menggunakan Shapiro wilk yang menunjukkan hasil 0,059>0,05 hal ini menunjukkan bahwa sampel terdistribusi normal. Hasil dilanjutkan dengan uji oneway anova yang menunjukkan hasil sig $0,000<0,05$ berarti menunjukkan adanya perbedaan daya hambat dari masing-masing formula. pada tabel hasil di atas dapat dilihat berdasarkan rata-rata daya hambatnya formula III yang memiliki daya hambat paling baik dari formula I dan II sedangkan daya hambat kontrol positif tidak berbeda signifikan dengan formula III. Pada kontrol negatif memiliki daya hambat karena pada formula ini mengandung pengawet yaitu EDTA yang memiliki fungsi sebagai bahan pengelat yang bekerja dengan mempengaruhi fungsi penghalang dan membran permukaan bakteri (Finnegan, S., \& Percival, S. L., 2015).

Pada uji efektivitas menunjukkan bahwa semakin tinggi konsentrasi uji, maka diameter zona hambat yang dihasilkan juga semakin besar. Menurut Davis dan Stout (1971), dimana kekuatan antibakteri dapat dikelompokkan sebagai berikut : Daerah hambatan $20 \mathrm{~mm}$ atau lebih : sangat kuat, Daerah hambatan 10-20 mm : kuat, Daerah hambatan 5-10 $\mathrm{mm}$ : sedang, Daerah hambatan 5 $\mathrm{mm}$ atau kurang : lemah. Berdasarkan kriteria tersebut, maka daya antibakteri ekstrak kulit nanas (Ananas comosus (L. Merr)) pada bakteri $S$. aureus setelah dikurang masing-masing formula dengan diameter zona hambat pada kontrol negatif, maka digolongkan tidak terdapat aktivitas antibakteri pada kontrol negatif karena zona hambat yang diperoleh yaitu $0 \mathrm{~mm}$, sedangkan pada konsentrasi 3\% termasuk sedang yaitu dengan zona hambat $5 \mathrm{~mm}$. Sedangkan pada konsentrasi $6 \%$ - 9\% termasuk kuat dengan zona hambat 10-20 mm. Konsentrasi yang efektif dan memiliki aktivitas dalam menghambat bakteri $S$. aureus ialah konsentrasi 9\% ekstrak kulit nanas.

3.7. Hasil Uji Panelis Sabun Cair Cuci Tangan Ekstrak Kulit Nanas

Uji panelis dilakukan untuk mengetahui tingkat kesukaan dari responden terhadap formula sediaan sabun cair cuci tangan ekstrak kulit nanas. Sebanyak 15 responden diminta untuk mengisi kuesioner yang kemudian diolah datanya dengan menggunakan data rata-rata dan secara statistik menggunakan Duncan's, pemaparan dari hasil uji panelis dapat dilihat pada tabel 23. Panelis kemudian diminta untuk menilai dan mengisi kuesioner dengan (1) bila tidak suka (2) bila kurang suka, (3) bila suka, dan (4) bila sangat suka. Hasil uji statistik menunjukkan bahwa dari ketiga parameter baik warna maupun tekstur dan aroma tidak berbeda signifikan antara formula 1 dan 2. Jadi dari data di atas diambil angka rata-rata yang tertinggi dan didapatkan hasil bahwa formula yang disukai baik dari segi warna maupun tekstur, dan aroma adalah formula 2 .

Tabel 6. Hasil uji panelis sediaan sabun cair ekstrak kulit nanas

\begin{tabular}{cc}
\hline Formula & Rata-rata Penilaian panelis \\
\hline $3 \%$ & $3,46 \pm 0,51^{\mathrm{a}}$ \\
$6 \%$ & $3,53 \pm 0,63^{\mathrm{a}}$ \\
$9 \%$ & $2,06 \pm 0,88^{\mathrm{b}}$ \\
\hline
\end{tabular}

\section{Kesimpulan}

Sabun cair dengan ekstrak kulit nanas (Ananas comosus (L.) Merr) memiliki kualitas mutu fisik dan stabilitas yang baik. Konsentrasi ekstrak kulit nanas (Ananas comosus (L.) Merr) dalam Formula sediaan sabun cair dengan konsentrasi $9 \%$ yang memiliki daya hambat yang paling tinggi terhadap bakteri $S$. aureus ATCC 25923 dan paling disukai panelis.

\section{Daftar Pustaka}


Agustina, L., Yulianti, M., Shoviantari, F. dan Sabban. (2017). Formulasi dan evaluasi sabun mandi cair dengan ekstrak tomat (Solanum lycopersicum L.) sebagai antioksidan. Jurnal Wiyata. Vol 4. No 2. p99105.

Ardina dan Suprianto. (2017). Formulasi Sabun Cair Antiseptik Ekstrak Ethanol Daun Seledri (Apium graviolens L.). Jurnal Dunia Farmasi. Vol 2. No 1. p21-28.

Badan Standar Nasional. (2017). Sabun cair pembersih tangan. SNI 2588:2017. Dewan Standarisasi Nasional. Jakarta.

Clinical and Laboratory Standard Institute (CLSI). (2009). Performance Standards for Antimicrobial Susceptibility Testing : Sebenth Informational Supplement . Vol. 26 (1) : M100-S17

Dabesor A. P., Asowata-Ayodele A. M. dan Umoiette P. (2017). Phytochemical Compositions and Antimicrobial Activities of Ananas comosus Peel (M.) and Cocos nucifera Kernel (L.) on Selected Food Borne Pathogens. American Journal of Plant Biology. Vol 2. No 2. pp. 73-76.

Damogalad, Viondy, Edy, H.J. dan Supriati, H.S. (2013). Formulasi Krim Tabir Surya Ekstrak Kulit Nanas (Ananas comosus L Merr) Dan Uji In Vitro Nilai Sun.

Davis, W. W. dan T. R. Stout. (1971). Disc plate methods of microbiological antibiotic assay. Microbiology. 22. p659-665

Depkes RI. (1995). Farmakope Indonesia Edisi IV. Jakarta : Departemen Kesehatan Republik Indonesia.

Erukainure, O.L., J.A. Ajiboye, R.O. Adejobi, O.Y. Okafor, S.O. Adenekan. 2011. Protective effect of pineapple (ananas comosus) peel extract on alcoholinduced oxidative stress in brain tissues of male albino rats. Asian Pac. J.Trop. Disease. 5-9.

Harborne, A. 1998. Phytochemical methods a guide to modern techniques of plant analysis, springer science \& business media
Hagerman, A. E, 2002. Tannin Handbook. Department of Chemistry and Biochemistry, Miami University.

Hernani, Bunasor TK, Fitriati. 2010. Formula Sabun Transparan Antijamur Dengan Bahan Aktif Ekstrak Lengkuas (Alpinia galanga L.Swartz). Bogor: Buletin Penelitian Tanaman Rempah dan Obat. 21 (2). 192 205.

Karou, S.D., Savadogo, A., Canini, A., Yameogo, S., Montesano, C., Simpore, J.,Colizzi, V. dan Traore, A. (2006). Antibacterial activity of alkaloids from Sidacauta. African Journal of Biotechnology. 5(12). 195-200.

Kemenkes. RI. (2010). Pedoman Perilaku Hidup Bersih dan Sehat. Jakarta: Kementrian Kesehatan Republik Indonesia.

KEMENKES. 2017. Peraturan Menteri Kesehatan No.32 Tentang Standar Baku Mutu Kesehatan Lingkungan Dan Persyaratan Kesehatan Air Untuk Keperluan Higiene Sanitasi, Kolam Renang, Solus Per Aqua, Dan Pemandian Umum. Jakarta: Republik Indonesia

Kristianti, A. N., 2008, Buku Ajar Fitokimia, Airlangga University Press, Surabaya

Kurniawan, D.W., Wijayanto, B.A. dan Sobri, I. (2012). Formulation and Effectiveness of Antiseptic Hand Gel Preparations Essential Oils Galanga (Alpinia galanga), Asian Journal of Pharmaceutical and Biological Research, 2(4).

Madduluri., Suresh., Rao, K., Babu. and Sitaram, B. 2013. In Vitro Evalution Of Antibacterial Activity Of Five Indigenous Plants Extract Against Five Bacterial Pathogens Of Human. International Journal Of Pharmacy And Pharmaceutical Sciences. 5 (4) : 679-684

Manaroinsong, A., Abidjulu, J. dan Siagian, K. (2015). Uji daya hambat ekstrak kulit nanas (Ananas comosus L) terhadap bakteri Staphylococcus aureus secara in vitro. Pharmacon Jurnal Ilmiah Farmasi UNSRAT. Vol 4. No 4. p27-33.

Manaroinsong, Andre. (2015). Uji daya hambat ekstrak kulit nanas (Ananas comosus L) 
terhadap bakteri Staphylococcus aureus secara in vitro. Pharmacon. Vol 4. No 4.

Pradipto, M. (2009). Pemanfaatan Minyak Jarak Pagar (Jatropha Curcas L.) Sebagai Sabun Mandi. Skripsi. Bogor: Ipb.

Price, S.A., dan Wilson, L.M. (2006). Patofisiologi, Konsep Klinis ProsesProses Penyakit. Edisi 6. p1271. Huriawati H, Natalia S, Pita Wulansari, Dewi Asih (eds), Penerbit Buku Kedokteran. EGC. Jakarta.

Punbusayakul N., Samart K. dan Sudmee. (2018). Antimicrobial Activity of Pineapple Peel Extract. Innovation of Functional Foods in Asia (IFFA) : Functional Foods: Trends in Research and Markets. University of Phayao. Phayao Province. Thailand.

Mediani, A., Abas, F., Tan, C.P., Khatib, A., Lajis, N.H. (2012). Influence of Growth Stage and Season on the Antioxidant Constituents of Cosmos caudatus. Plant Foods Hum. Nutr. 67. p344-350.

Prasanti, Ade Nur. (2010). Faktor-Faktor yang Mempengaruhi Karier Staphylococcus aureus pada Siswa SMA yang Sehat di Semarang. Laporan Penelitian Fakultas Kedokteran. Universitas Diponegoro.

Rini, Anggy Rinela Sulistya, Supartono, dan Nanik Wijayati. (2017). Hand Sanitizer Ekstrak Kulit Nanas sebagai Antibakteri Staphylococcus aureus dan Escherichia coli.Indonesian Journal of Chemical Science. Vol 6. No 1. p61-66.

Tadros. (2005). Applied Surfaktan: Principles \& Application. Wiley-Vch Verlag Gmbh \& Co, Weinhem.

Muliyawan, D. dan Suriana, N. (2013), A-Z Tentang Kosmetik. Jakarta. PT Elex Media Komputerindo.

Finnegan, S. dan Percival, S. L. (2015). EDTA: An Antimicrobial and Antibiofilm Agent for Use in Wound Care. Advances in wound care. Vol 4. No 7. p415-421.

Thaker, H.C., Brahmbhatt, M.N., Nayak, J.B. dan Thaker, H.C. (2013). Isolation and identification of Staphylococcus aureus from milk and milk products and their drug resistance patterns in Anand, Gujarat. Vet World. Vol 6. No 1. p10-13.

Warnida H., Sapri, Sukawaty Y. dan Dharma P.A. (2014). Formulasi Mikroemulsi Minyak Ikan Patin (Pangasius djambal) dengan Variasi Polysorbate 80 Sebagai Surfaktan. Media Sains. Vol 7. No 2. p221-226.

Wiharningtias Indria, Waworuntu Olivia, Juliatri, (2016). Uji Konsentrasi Hambat Minimum (KHM) Ekstrak Kulit Nanas (Ananas comosus L) Terhadap Staphylococcus aureus. Pharmacon. Vol 5. No 4.

Wulansari, N. T., dan Parut, A. A. (2019). Pengendalian Jumlah Angka Mikroorganisme Pada Tangan Melalui Proses Hand Hygiene. Jurnal Media Sains, Vol 3. No. 1, 7-13. 